See discussions, stats, and author profiles for this publication at: https://www.researchgate.net/publication/339352789

\title{
Gay the right way? Roles and routines of Irish media production among gay
} and lesbian workers

Article in European Journal of Communication · February 2020

DOI: 10.1177/0267323120903684

CITATIONS

6

2 authors, including:

Páraic Kerrigan

University College Dublin

25 PUBLICATIONS 53 CITATIONS

SEE PROFILE

Some of the authors of this publication are also working on these related projects:

Queering in the Years: Gay (In)Visibility in Irish Media, 1974-2008 View project
READS

82 


\title{
Gay the right way? Roles and routines of Irish media production among gay and lesbian workers
}

European Journal of Communication

(C) The Author(s) 2020 Article reuse guidelines: sagepub.com/journals-permissions DOI: I0.1 I77/0267323|20903684 journals.sagepub.com/home/ejc

@SAGE

\section{Anne O'Brien}

Maynooth University, Ireland

\author{
Páraic Kerrigan \\ University College Dublin, Ireland
}

\begin{abstract}
This article explores how gay and lesbian identities are incorporated, or not, into the roles and routines of Irish film and television production. Data were gathered in 20I8-2019 through semi-structured interviews with a purposive, snowball sample of 10 people who work in the Irish industries. The key findings are that for gay and lesbian workers their minority sexual identity impacts on the roles that they are likely to be included and excluded from. Sexuality also affects their promotion prospects and their career progression. Similarly, in terms of routines of production, gay and lesbian workers are associated with certain genres, based on stereotypical assumptions about their sexual identities by their hetero-managers and colleagues. In short, Irish gay and lesbian media workers articulated an overarching tension between the heteronormativity of the industry and the queerness of the gay and lesbian media worker. Some workers respond to that tension by adopting a homonormative approach to work while others attempt to forge a queer way of producing.
\end{abstract}

\section{Keywords}

Gay, lesbian, media, production studies, sexual identity

\section{Corresponding author:}

Anne O'Brien, Maynooth University, Maynooth W23F2H6, Ireland.

Email: anne.obrien@mu.ie 


\section{Introduction}

This article examines the ways in which gay and lesbian identities are incorporated, or not, into production roles and the everyday routines of production in the Irish film and television industries. To date, Queer Media Studies and queer media activism more broadly have been concerned primarily with matters of representation and how industry dynamics shape queer representations (Kerrigan, 2017, Kerrigan and O'Brien, 2018). Himberg (2018) notes how gay activists have given little attention to labour issues among LGBT media workers and several other scholars, gesture towards further incorporating sexuality-based labour issues with representational ones (Martin, 2018b; Schiappa et al., 2006). This analysis aims to address that gap, by arguing that for gay and lesbian workers, their minority sexual identity impacts the roles that they are likely to be included (and excluded) from and affects their promotion and career progression. Similarly, in terms of routines of production, gay and lesbian workers are associated with certain genres, based on stereotypical assumptions about their sexual identities by their hetero-managers and colleagues. In short, Irish gay and lesbian media workers reveal an overarching tension between the heteronormativity of the industry and the queerness of the gay and lesbian media worker. Some workers respond to that tension by adopting a homonormative approach to work while others attempt to forge a queer way of producing. In this context, homonormative is understood as 'a politics that does not contest dominant heteronormative assumptions and institutions, but upholds and sustains them, while promising the possibility of a demobilized gay constituency and a privatized, depoliticized gay culture' (Duggan, 2002: 179 also Berlant and Warner, 2002) and queer is used broadly to refer to the disruption of dominant ideologies and practices (Cohen, 1997; De Lauretis, 1994; Giffney, 2009).

\section{Queer production studies}

Within Media Studies, a concern with LGBT sexual identities has been adopted for the purpose of analysing screen texts, (Beirne, 2008; Dyer, 1990; Gross, 2001; Russo, 1981); as well as in approaches to understanding screen audiences (Dhoest, 2016; Kern, 2014); and in the context of new media landscapes (Alexander, 2004; Driver, 2006; Sender, 2012). However, queer sexualities in general have not been a central concern within the sub-discipline of Production Studies. Key texts in the field have failed to address sexual identities as a dimension of media work (Banks, 2007; Deuze, 2009, 2011; Florida, 2002). A small number of studies have taken LGBT sexual identity as a focus and have been situated primarily in the US context. Queer Production Studies is invested, as Martin (2018a) argues, "in the many facets of queer production and the production of queerness' (p. 4). Some of these early works focused on closeted homosexuality in Hollywood, in the case of Rock Hudson. Meyer (1991) explored how the Hollywood film industry of the 1950s and 1960s curated and managed Rock Hudson's gay sexuality to conform to heteronormative paradigms. Dyer (2002) similarly examined the production of Hudson's star identity and public perception of sexuality. More recently, Queer Production Studies has focused on industrial dynamics, particularly on the ways in which 
networks and broadcasters engaged with queer content and queerness. Aslinger (2009) examined programming strategies within the US cable channel Logo TV. Himberg (2014) similarly interrogated institutional practice and beliefs surrounding lesbian content, while Martin (2015) examined the production of gay black characters on the blackcast sitcom, using interviews with writers. Queer reception has been a smaller focus of queer production studies, with Lieb's (2016) research examining 'fauxmosexuality' in the construction and reception of music videos (in Mayer et al.). Martin (2018a) examines the ways that casting functions as a practice that works within 'best actor' discourses that 'insulate the television industry from charges of deliberately failing to cast gay actors in projects' (p. 18). Paratextuality, the study of how audiences make sense of media texts through extra-textual materials, has also become a site of research within Queer Production Studies (Cavalcante, 2013; Draper, 2012; Ng, 2018). The development of a sub-field of Queer Production Studies has been further marked by the publication of a special issue of the Journal of Film and Video, titled 'Queer Production Studies' (Martin, 2018a). The sub-field and pervading US-centric research has been localized in the European context by Vanlee's (2019) study of the production of LGBT characters in Flemish television fiction. To contribute further to the growing contexts in which queer production studies research takes place, the key focus of this article is on the ways in which gay and lesbian identity are incorporated, or not, into production roles and routines in the Irish context, to either reassert heteronormativity or to challenge the same, through queer practices.

\section{Methodology}

Ireland is a particularly interesting site for a case study of how gay and lesbian sexual identity shapes screen production work. On the one hand, Ireland has in recent years elected an openly gay Taoiseach (the elected political-managerial role that is equivalent to the Prime Minister), passed a landmark referendum in favour of same-sex gay marriage in 2015 and seen drag queen Panti Bliss achieve global recognition for the theatre performance of the Noble Call, a viral speech uploaded to YouTube, lauded for its call for tolerance, equality and justice for LGBT minorities. On the other hand, Ireland is problematic because its record on diversity in screen production is so poor. In terms of the size and structure of the sector, in 2016, the film and television industries in Ireland supported nearly 15,000 full-time jobs and the sector attracted over $€ 150$ million in inward investment (Department of Arts, Heritage \& The Gaeltacht, 2016). At present, the broadcast sector has two dual-funded, public service broadcasters, RTÉ and the Irish language station TG4, and one commercial broadcaster Virgin Media. Over 140 small- to medium-sized independent screen production companies are active in the industry. Because of its small scale there is very significant overlap between film and television with workers moving frequently between both sectors as well as working internationally. To date, there are no national statistics available on the representation of LGBTQ workers in the Irish film and television industries.

Data for this case study were collected in 2018-2019 through semi-structured interviews with a purposive, snowball sample of 10 people who are currently working in Irish 
television and film production. Gay and lesbian are the identity terms used in this article, as that is how the participants identified. None of these terms presuppose the existence of a clear group or identity, but they refer to some widely used discourses and categorizations. LGBT is also used within this article to signal not only its common use as a term for sexual and gender minorities, but also as a reflection of the Irish media landscape, which is largely heteronormative in its makeup and offers very little in terms of queerness, either in terms of representation or production (see Kerrigan and O' Brien, 2018). Although queer, queerness and queering have been used in broad ways (Cohen, 1997; De Lauretis, 1994; Giffney, 2009), the terms when used in this article refer to the disruption of dominant ideologies and practices within the Irish media industry by gay and lesbian workers. Media workers were defined broadly to include an elite of creative producers, as well as middle-ranking operatives and low status administrative workers, across multiple genres of feature, entertainment, news, reality, daytime and talk programmes. The sample was collated initially through preliminary interviews with informants who were personal contacts and who openly identified as gay or lesbian both inside and outside of the media industry. Thereafter, other potential participants were suggested by respondents, and these were subsequently pursued in further interviews.

All information that could identify any of the individuals described in the study was removed or changed, apart from loose job descriptions. A key concern of the majority of respondents was that the data would be anonymized. This related to their anxieties about possible reputational damage that might accrue to identifying inequalities in the context of a small nation state with a highly networked industry. Furthermore, seven additional potential participants who identify as gay or lesbian declined to participate in the research, stating that they did not wish to speak out in case they were identified by their employers or outed in the workplace. This was their position despite being guaranteed anonymity in the research. The findings discussed below are reflective of the participants' current experiences of media work as gay and lesbian workers.

Table 1 represents the employment details of snowball sample of 10 gay and lesbian media workers.

Table I. Employment details of snowball sample of 10 gay and lesbian media workers.

\begin{tabular}{llll}
\hline Identifier & Job title & Contract & Employment status \\
\hline A & Director & Freelance & Self-employed \\
B & Producer-director & Independent company & Owner \\
C & Director & Freelance & Self-employed \\
D & Camera operator & Freelance & Self-employed \\
E & Producer-director & Independent company & Full-time \\
F & Researcher & Employee & Full-time \\
G & Producer-director & Independent company & Owner \\
H & Producer-sound & Employee & Full-time \\
I & Producer-researcher & Freelance & Part-time \\
J & Presenter-researcher & Employee & Full-time \\
\hline
\end{tabular}




\section{Findings}

\section{Allocation of roles}

In Irish film and television production, gay and lesbian sexual identity was linked by respondents to labour practices through the allocation of roles within the production process. The association of roles with sexual identity was a subtle structural principle enacted in the labour practices of a community of workers, both men and women, that served to reproduce stereotypical ideas about what 'types' of people did particular kinds of work. Sometimes being lesbian or gay got in the way of people getting particular roles or achieving promotions. As a researcher, who was openly out to her colleagues, put it,

heteronormativity is much stronger in Ireland than we think it is, and I always felt that there was a little bit of that going on, but I couldn't quite put my finger on it until I left Ireland and worked in media outlets around Europe. (F)

Another producer noted that he left a media workplace as a result of being 'punished for (his) sexuality' (B). Having expressed interest in pursuing a particular kind of role in a specific department, the producer was sent to a different role in another department that was completely out of his field and range of interest, in an attempt 'to break (his) spirit' (B). Many of the respondents working across the Irish media industry noted that sexuality was often marked within the workplace in problematic ways, where naming their sexuality publicly resulted in negative decisions around the allocation of roles, or a lack of success in obtaining any promotions. A sound technician explained that 'people would have been afraid to promote me because I was very straight forward and open [about being gay]' (H). Despite this, a smaller number of the participants had a tendency to deny that sexuality (or gender) played any part in role allocation. This was done in a way that presented gender and sexuality as unconnected to role allocation, which one employer claimed was always based on unnamed but nonetheless 'objective' meritocratic criteria - that of being 'good' for a particular role. Asked if sexuality played a part in recruitment that director denied this and noted, 'I know I make choices based on how suited somebody is to being a part of a team and what they can bring to that story' (C).

The process of role allocation according to stereotypical ideas about sexuality could sometimes have positive outcomes for gay and lesbian workers in the sense that there was an industry understanding that the insights required to write or direct LGBT characters were an asset and could lead to the commissioning of a gay or lesbian writer or director. This scenario was described by one respondent:

If you're trying to do a story that is about identity, particularly sexual identity, then I think an LGBT director has a better chance, just because you can go to the well there, it's not something you're researching outwardly. I think your identity is really important. (A)

That same director described getting commissioned to write a film script not only because of the availability of their insight due their sexuality, but also because of the 
importance of the production company being seen publicly not to misappropriate sexual identity. As they said,

I got asked to write a gay comedy because I was gay [ . . ] for a big production company in LA [...] but I think the reason is (that) otherwise they'll be called out for inauthenticity, or homophobia [.. .] so I think they were just being very smart and strategic . . . (A)

Role allocation became positive in another set of circumstances for a presenter and producer, who noted that their sexuality was considered 'hip and cool' and 'ticked boxes' for their employer. A presenter was clear that the cache of being gay earned more publicly visible jobs in front of camera (E). There was also the perception among some of the participants that gays and lesbians were more likely to flourish within factual and factual entertainment programmes. For instance, one producer stated that he would prefer to hire someone that identifies as LGBT due 'their broad taste' (B). He admitted that this approach 'is stereotypical, and I am playing to stereotypes' (B). Nonetheless, in some sets of circumstances within the Irish media industry, identifying as gay or lesbian proved an advantage in achieving some roles. It also highlighted the ways in which some employers hired gay and lesbian workers to mitigate criticisms about a lack of diversity on screen and also to avoid accusations of representing or creating gay characters that were stereotypical in any way. This is similarly reflective of Julia Himberg's (2018) argument pertaining to how the television industry is an 'intermediary or an interpretive space between the co-optation and the facilitation of LGBT' identities (p. 13). Although specific to the US context, Himberg's argument resonates within the Irish screen industry, where senior managers working in production incorporated gay and lesbian media workers into their crews, in some instances to look like they were outwardly meeting some sort of diversity remit, but in others cases, they read gay and lesbian workers as being arbiters of good taste in terms of specific genres, like entertainment or factual programming and subsequently wanted to co-opt aspects of their gay and lesbian sexual identity and allocated them specific roles.

In addition to getting certain types of work as a result of stereotypical thinking that connected them with some roles, other respondents agreed that they actively co-opted stereotypical conceptions of homosexuality to their own end in order to access production work. They did this to varying degrees and with varying levels of comfort in so doing. As one lesbian respondent put it,

It took me time to use my sexuality, to use the fact that being gay seemed to get me further along, where I would get more gigs because I didn't seem to be on the path of getting married [. . . It was definitely a conscious thing that I picked up on really fast [. . .] where I kind of became one of the boys in a way. (D)

That lesbian woman's sexuality was presumed to mean that she did not suffer the same constraints as other hetero women who might intend to have children. She observes,

As I got older, I wasn't (assumed to be) settling down [. . . ] whether I was with someone or not I was seen as more available, that I had a tendency not to say no to work, or to have constraints to my time [. . . I I was actually told to my face [. . . ] that I would do better in the industry because I didn't have to take maternity leave. (D) 
In another instance, a presenter used their sexuality to get a job on a television documentary about an LGBT issue (E). Another respondent declared their sexuality publicly to an employer in order to get work on a production that was shooting with the LGBT community (I). The respondents revealed that there were processes and structures that connected sexuality with the allocation of roles in media production. In some instances, it prevented promotion and progression within the structures of organizations, but in others, it enabled respondents to get work and achieve some stability or continuity of work, it even allowed for some activism about gay and lesbian people accessing production work. One researcher noted how they worked with a producer who was gay and was active about their sexuality in trying to incorporate gay and lesbian people in production work: 'He was adamant that he actually articulated his own personal activism and bring it to bear in his programme making and he encouraged us to incorporate gay and lesbian voices on programming and be heard on our terms' (I). As the data reveal, sexual identity and role allocation was very much a two-way process between gay and lesbian media workers and the media companies. For the workers, sexuality often provided a gateway to work in production, but could see them become mired in problematic stereotypes and limitations as well. In terms of media institutions, gay and lesbian media workers could be understood to be contributing to a diversity remit or a 'tick, box' exercise around diversifying the workforce. These structuring dynamics of production work for gays and lesbians demonstrates what Patrick Mullen (2012) has referred to as a queer use value. This reliance on gay and lesbian media workers for diversity and allocation of roles supports what Martin (2018b) calls, 'capitalism's production of queer subjects as a mechanism to accommodate its own economic and cultural desires' (p. 289). Having gay and lesbian media workers visibly work with and on gay issues avoids claims and criticisms of a singular, heteronormative approach on the part of the media industries.

The queer use value of gay and lesbian workers is further exemplified in the context of leave for childcare. Given that maternity leave raises human resource concerns in media production more generally (Wreyford, 2013), there was a perception that gays and lesbians automatically avoided maternity leave and this allowed them to find more stability in media work relative to heterosexual women, who were more likely to be associated with maternity leave requirements. These forms of queer use value could be seen as assets in an industry that was inherently precarious, because lesbian and gay workers were stereotypically assumed to not have to participate in the perceived reproductive demands of heteronormativity. It could be surmised then that although progression and promotion was stifled due to gay and lesbian identification in media work, access to production could on occasion offer some queer advantage. In addition to experiencing a differentiation in role allocation on the basis of sexual identity, so too with regard to the everyday processes of production, gay and lesbian workers often saw that they were set apart from the heterosexual normative worker.

\section{Routines of production}

On numerous occasions, respondents experienced the routines of production, in the forms of the perspective applied to content and engagement with genre differently from heteronormative colleagues. As a researcher succinctly put it, the routines of film and television production involved 'the reification of heteronormative standards in terms of 
topics, in terms of who gets the job, and in terms of the discourses that we use' (F). She was clear that these 'are all far too reaffirming of heteronormative tropes' (F). In terms of content, the researcher observed that there were assumptions at play that tended to produce and reproduce the same (heteronormative) perspectives because of how the routines of screen production worked. As she put it,

the presumption is that the gay man knows about entertainment, he knows about fashion, he might know about home décor. A lesbian woman doesn't fall into any of these things and so definitely there's a massive cultural assumption there and [ . . . ] for someone who might identify as heteronormative, it's so much easier for them

to fit with the dominant and mainstream point of view $(F)$. The intersection of sexual identity with the production of certain kinds of content resonated for respondents in a number of ways. Some respondents did agree that they could create 'gay content' but questioned what it might mean for content to be gay. As one writer proposed, 'maybe the metrics is if one or more characters at the centre of the story is gay, then it can be claimed as part of that experience' (A). For another producer, gay identity was something that was routinely considered in her own production practices and shaped her approach to casting within a range of entertainment shows. 'Whether it's a show about houses, property, weddings or dating, I would feel very strong that the casting would represent straight people as well as LGBT people' (E).

However, for some respondents, their sexual identity was something that got intrinsically connected to the type of content that they were suggesting, in ways that were not positive or voluntary and in ways that were not experienced by heterosexual workers. For instance, a lesbian researcher's pitch was collapsed into her sexual identity and consequently dismissed. As she recounts, 'I pitched some sort of a package pertaining to LGBT affairs and the idea was shot down and I got this casual remark of, "Oh you know, you need to separate the personal from the professional"' (F). Sometimes, gay or lesbian writers or directors were reduced to being mainly associated with content about sex, but as a respondent noted, 'Everything doesn't need to be percolated down into the area of sex, you know and that's not me being coy, I just don't see it' (A). However, even if gay or lesbian directors 'played to type' and wanted to make a film that was about sex, they were constrained by the 'mainstream' view of homosexual scenes as fundamentally riskier than hetero scenes. As one writer described,

That's something that's on my slate [. . .] A really adult sex comedy [. . .] But it's going to be a real risk [...] The question is, is the Irish audience, or the Irish networks or the Irish commissioners, are they ready for an explicitly sexual gay story? (A)

The absorption of the risk of shooting a gay sex scene for mainstream cinema was understood by the respondent to require a director that had 'credit' with producers and audiences and surplus credibility that could mitigate the risk of a homosexual scene. The idea of explicitly sexual gay content was seen by production personnel as riskier than the normative or hetero equivalent scenes. Therefore, people who wish to produce this content have to be willing to take that risk, or be so bankable that they are given a pass to 
produce this type of work. Gay content was framed as outside the norms of routine production in these cases.

LGBT perspectives among gay and lesbian media workers were also positioned as an outlier point of view that had to adapt and conform to the heteronormative practices that remained dominant and unquestioned. Thus, the 'routine' prioritization of heteronormativity in media workplaces serves to shape the relationship between sexual identity and the content that can most easily be produced. One producer described how one of their ideas was 'vetoed' by a broadcaster because of its gay content:

I felt that there should have been a monthly magazine gay programme [. . .] to show the normalisation of the gay experience within [Ireland]. I felt that [the broadcaster] was missing a trick by not being ground-breaking and showing it in any way. Every attempt I made to do that was shot down. (B)

Many of the participants noted the ways in which content pertaining to LGBT issues became regulated and monitored closely by the broader production team. They also noted that there was greater scrutiny and particular demands with regard to gay content. In one such case, a respondent noted how an LGBT participant was pulled from a live programme that was to discuss a gay issue, because the item was considered to be scheduled 'too early in the evening' for the (hetero) television audience (H). Similarly, a researcher commented that much LGBT content that they pitched to production teams was often ignored or at the very best, watered down. In one case, the production team argued to the researcher that this was due to the fact that 'the majority of our viewers were male, over the age of 55 and came from the countryside' (F). Gay and lesbian media workers found that the creation of content was regulated by the perceived palatability of the content for the imagined (normatively hetero) audience of viewers.

This sidelining of the queer perspective resulted in the unstated norm that LGBT content should have an invisible quota, that there should be a limit put on this account of human experience. As one writer noted,

People are already asking me are you going to keep making stories with gay people, as if there's a quota [and] I'm shooting myself in the foot. I mean the mainstream and this idea are not in competition with each other and they can both happen at the same time and it's a real struggle, people are like 'Oh he's done the gay thing and maybe now he's going to do the thing where there aren't any gay characters', Like fuck that, you know what I mean? That's not up for debate. (A)

The attempts by gay and lesbian media workers to push the limits and diversity of Irish screen production clashed with this perceived necessity of palatability for heteronormative audiences. As a result, 'acceptability' was a conceptual shaping factor in content generated by gay and lesbian workers. Acceptability or respectability, attempts to 'integrate LGBT people within the status quo' and frame homosexuality as legitimate and respectable (Vaid, 1995: 54). Evelyn Brooks Higginbotham (1993) further argues that respectability dictates that 'member of the oppressed minority must aggressively adopt the manner and moral that been deemed virtuous by [the dominant] group' (p. 42). 
This requirement of respectability or acceptability shaped a lot of the LGBT content suggested by gay and lesbian media workers, so that the Irish media industry maintained heteronormative hegemony, negating the supposed advantage held by gays and lesbians of being able to draw on their experiences and identities to form authentic content.

This positioning outside the norms of production, coupled with the pursuit of mainstream palatability and acceptability, reflect homonormative paradigms in the Irish industry that marginalized and limited sexual and gender expression. Ng (2013: 273) similarly reflects these homonormative dynamics in the context of Logo TV in the United States, where she notes that constructions of homonormativity were enabled 'by the concomitant marginalization of other queer bodies and practices'. $\mathrm{Ng}$ notes how content on a specifically LGBTQ identifying network was made palatable for broader, non-LGBT audiences, at the expense of being in any way queer. The production of homonormative content plays out in a similar way in Irish media industries, where homonormative paradigms were forced on the gay and lesbian workers by their hetero-managers. This was underpinned by an overarching tension between the heteronormativity of the Irish media industry and the potential for queer offerings by gay and lesbian workers. The maintenance of this palatable, homonormativity within routines of production, particularly around queer content, is reflective of the competitive domestic market that characterizes Irish media industries. Due to a lack of funding, financial and economic pressures can tend to purvey gay and lesbian content in a universalizing, homonormative and acceptable fashion. Gay and lesbian content needed to be safe and within heteronormative standards in case it was perceived as something that might 'rock the boat' or could risk losses in investment or funding (A, B, F, G).

Although, routine notions of acceptability or respectability and assumed perceptions of imagined audiences often served to invisibly curate LGBT content, identifying as gay sometimes still resulted in a worker's ideas being very visibly and overtly dismissed. A producer described how content was 'vetoed' not because of a gay perspective in the content but because the broadcaster was dismissive of the idea or person proposing it, despite the fact that the particular idea and the producer later went on to be highly successful elsewhere. As the producer recounted,

I said you need to do this show and they said, 'Don't be ridiculous' [ . . . and that was because of my sexual identity. Even if I could tell they thought my ideas were good, they would dismiss it because of my sexuality. So as soon as I went and became an independent producer [. . .] I became quite friendly with the head of [another broadcaster] and I told them about the idea and they gave me money to make a pilot, and it got commissioned, and it became a network daytime show. (B)

A smaller number of respondents noted the ways in which their sexuality could be an influence on the routine production of content in a positive way. As one writer put, their sexuality led them to

write people that I knew hadn't been represented before . . . the objective was to write a gay couple that I would recognise from my own life and to write a couple for whom their sexual orientation was an element of their story, but not the whole thing in some way. (A) 
Another producer was clear that as a lesbian she was able to comment on gay content and shape it with an authority that her straight colleagues did not feel they possessed. As she described,

I was in the edit suite and we were editing an episode with these two guys who were getting married and in the opening sequence [. . .] there was a lot of kissing, like a lot of kissing and you're looking at it going, get a room, but the other two people in the edit suite who are not gay, almost felt they couldn't say that [. . . ] so there's simple little things that I would be comfortable in saying as a lesbian. (E)

Another researcher who had managed to get an internationally famous drag queen on their show, despite objections from the producers, recounted that

the ratings went through the roof. So, as a result, I think it broadened the horizons of the show, because the show was also very heteronormative and very stereotypical ... So, I kind of diversified that a little bit. I think as a result of that example, they started to open their eyes a bit more to small LGBT tropes and different characters and that kind of thing. (F)

Due to the fact that gay and lesbian media workers could draw on their unique experience and perspective, they could push the routines of content production and force production teams and mainstream audiences to confront the fact of LGBT lives and perspectives. In doing so, this diversified content on screen and in some instances, proved the economic viability of having LGBT content on television, through successful ratings. While gay and lesbian workers could successfully shift routines towards greater inclusivity, another structural barrier to full participation in the film and television workforce was constructed from a pattern of allocating gay workers to particular genres of programme and excluding them from others.

\section{Gay genre allocation}

As well as lesbian and gay identities disrupting the routine production of heteronormative content, lesbian and gay workers also tended to be associated with the production of certain genres of programming. Respondents understood that there was a prevailing presumption that queer workers could address only certain dimensions of the audience's interest, mainly in soft genres. A producer claimed,

I was particularly drawn to creating programme ideas in the factual entertainment area [. . .] I think in the genres of entertainment and factual entertainment, there's more scope to be very creative in the programme ideas, so possibly LGBT people can flourish in those genres. (E)

A researcher observed, 'One of my previous colleagues was a gay man and he very much believed that working in entertainment, it got him a lot of places because he was a gay man' $(F)$. The types of genres in which gay and lesbian respondents believed they were most likely to work were drama, entertainment and comedy with fewer respondents seeing openings for gay and lesbian workers in news and current affairs genres for instance. 
In addition, sometimes the softer genres were marginalized and not given the credit, attention or status that harder genres received. There was a sense that comedy for instance was neglected by a broadcaster, and that gay representation within that genre was marginalized. As one writer noted,

They don't have a great track record of hiring Irish directors and their output isn't nearly as broad as it needs to be and there really isn't much of a comedy department to speak of, so I find it impossible to get anything in there and when I look at their stuff on TV, I think our community is massively under represented, but I'm struggling to think of LGBT representation in drama or comedy on [that broadcaster]. (A)

Moreover, in film production, there was a similar dynamic that gay comedy films were not perceived to be bankable in terms of the mainstream and were automatically relegated to a softer and less valued arthouse genre. As that writer explained,

My struggle is getting gay characters into mainstream films and that's my thing. It's easier to make an alternative, low budget drama with gay characters, because it's a marginalised area of the market. What I have always tried to do is be in the mainstream with these characters, that's the struggle. (A)

The presumption that gay people did certain genres, could perhaps constitute an advantage to gay and lesbian people who wanted to work in those genres, but it was also a barrier for LGBT media workers who wanted to access content production outside of those areas. This dynamic set off a vicious cycle perpetuating a 'gays do entertainment/ drama/comedy and not news' 'rule' of screen production. This was further reinforced by the fact that gay workers in the news and current affairs department were something of a rarity. As a researcher observed,

When it comes to news for example, in general terms, no, my sexuality is a hindrance, not a help . . . Can you imagine if we had a Head of News who was openly gay? I beg to see the day that that happens. (F)

However, the researcher was not optimistic that this would occur and with stark consequences for her own sense of her potential place and future in news production. As she put it, 'It won't happen in the next few years, I highly doubt ever seeing that happen. As a result, I cannot see myself working in the media in Ireland ever again' (F). For one respondent, this 'choice' around what genre of programme he wanted to work in was used as a mechanism to bully him by forcing him to work in genres he explicitly said he did not want to work in and excluding him explicitly from those where he did want to work. As he put it,

I came out of training and they said to me, 'So what department do you want to go to?' And obviously, I said entertainment and arts. (They said) 'Well where do you not want to go to?' I said 'Well there's no point sending me to Sport, Irish language, or Religion'. So, in order, they sent me to three months sport, three months Irish language, three months religion. That was to break my spirit, I don't know what the fuck it was, but it was a very unpleasant way to do things. (B) 
Ultimately, for people who wanted to focus on specifically or explicitly 'queer content' there was a particular challenge with trying to do so in an Irish context and a sense that this would only work at an international level. As a researcher put it,

I mean it's sad that queer identity is treated as a topic, rather than a state of being, but if you zone in on queer identity as your area, then it's going to be very difficult. You're going to get the work that you want, but it's going to be very international [. . .] in the US, as that is where most queer representation is probably the strongest. (F)

\section{Conclusion}

Stereotypical ideas about gay and lesbian identity continue to be operationalized within the production structures and routines of Irish film and television production. Gay and lesbian identities have been shown to be shaped by work, which simultaneously shapes workers' experiences of media industries. Identity impacts on the roles that are seen as appropriate or likely to be filled by people of a queer sexual orientation. LGBT sexual identity could dictate who got which roles in production and equally who was likely to be excluded from other roles. In turn, potential progression routes through promotion were shaped by who was deemed suitable for promotion, which indicates practices of vertical segregation on the basis of LGBT sexual identity in both film and television. This production practice of role allocation was not a simple case of obvious bias or discrimination that was easily evidenced by respondents, rather it was their understanding that a subtle structuring principle was in play which was built on stereotypes and traditional expectations about what being gay or lesbian meant for workers and for film and television production. In terms of the usefulness of a gay or lesbian point of view in production, respondents note that it was assumed they would be interested in a limited range of topics, while they could produce gay content that was intrinsically identified with them as individuals, it was assumed content about LGBT sexual identity had to be about sex, but any attempt to produce explicitly gay sex scenes was deemed beyond the routine possibility of screen production. Gay content was often dismissed as inappropriate for the regular schedule, or not for a general audience's consumption. It was ignored or watered down or entirely dismissed when it was proposed by gay and lesbian workers. This in and of itself revealed the ways in which the heteronormativity of the Irish industry produced an overarching tension with the potential queer offerings of gay and lesbian workers. This tension served as a structuring device that shaped how workers experienced screen production centred on the association of gay and lesbian workers with certain genres but not others within media industries. This meant that gay and lesbian people did not participate on an equal basis with heteronormative colleagues who did not suffer that bias. In short, gay and lesbian workers were more constrained in role allocation, routines of production and engagement with genres of production than their heterosexual colleagues. While generalizing on the basis of a very small national sample is always problematic and this research makes no claims at that level, nonetheless this research sets out some of the key areas in which queer workers see that their working lives are different from those of their straight peers. The lack of equality among workers based on these distinctions around LGBT sexuality is an area that requires more extensive and further in-depth study in order to better understand how sexuality can generate inequality. 


\section{Funding}

The author(s) received no financial support for the research, authorship, and/or publication of this article.

\section{ORCID iD}

Anne O’Brien (iD https://orcid.org/0000-0003-2306-1415

\section{References}

Alexander J (2004) In their own words: LGBT youth writing the world wide web. New York: GLAAD Center for the Study of Media and Society.

Aslinger B (2009) Creating a network for queer audiences at Logo TV. Popular Communication 7(2): 107-121.

Banks M (2007) The Politics of Cultural Work. New York: Palgrave Macmillan.

Beirne R (2008) Lesbians in Television and Text After the Millennium. New York: Palgrave Macmillan.

Berlant L and Warner M (2002) Sex in public. In: Warner M (ed.) Publics and Counterpublics. New York: Zone Books, pp. 187-208.

Cavalcante A (2013) Centring transgender identity via the textual periphery: TransAmerica and the 'Double Work' of paratexts. Critical Studies in Media Communication 30(2): 85-101.

Cohen C (1997) Punks, bulldaggers and welfare queens: The radical potential of queer politics? GLQ 3(4): 437-465.

De Lauretis T (1994) Habit changes. Differences: A Journal of Feminist and Cultural Studies 6(2-3): 296-313.

Department of Arts, Heritage \& The Gaeltacht (2016) Written Answers (Question to Minister for Arts, Heritage and the Gaeltacht). Available at: https://beta.oireachtas.ie/en/debates/question/2017-07-13/460/.

Deuze M (2009) Media Work. Cambridge: Polity.

Deuze M (2011) Managing Media Work. Thousand Oaks, CA: SAGE.

Dhoest A (2016) Audiences out of the box: Diasporic sexual minorities viewing representations of sexual diversity. European Journal of Cultural Studies 19(6): 690-707.

Draper J (2012) Idol speculation: Queer identity and a media-imposed lens of detection. Popular Communication 10(3): 412-431.

Driver S (2006) Virtually queer youth communities of girls and birls: Cultural spaces of identity work and desiring exchanges. In: Willett R (ed.) Digital Generations. Mahwah, NJ: Lawrence Erlbaum, pp. 229-246.

Duggan L (2002) The Incredible Shrinking Public: Sexual Politics and the Decline of Democracy. Boston, MA: Beacon Press.

Dyer R (1990) Now You See It: Studies on Lesbian and Gay Film, 2nd edn. London and New York: Routledge.

Dyer R (2002) The Culture of Queers. New York: Routledge.

Florida R (2002) The Rise of the Creative Class. New York: Perseus.

Giffney N (2009) Introduction: The 'Q' word. In: Giffney N and O'Rourke M (eds) The Ashgate Companion to Queer Theory. Burlington, VT and Farnham: Ashgate, pp. 1-13.

Gross L (2001) Up from Invisibility: Lesbians, Gay Men, and the Media in America. New York: Columbia University Press.

Higginbotham EB (1993) Righteous Discontent: The Women's Movement in the Black Baptist Church, 1880-1920. Harvard, MA: Harvard University Press. 
Himberg J (2014) Multicasting: Lesbian programming and the changing landscape of cable TV. Television \& New Media 15(4): 289-304.

Himberg J (2018) The New Gay for Pay: The Sexual Politics of American Television Production. Austin, TX: University of Texas Press.

Kerrigan P (2017) Respectably gay: Homodomesticity in Ireland's first broadcast of a homosexual couple. In: Dhoest A, Szulc L and Eeckhout B (eds) LGBTQs, Media and Culture in Europe. London: Routledge, pp. 13-28.

Kerrigan P and O' Brien A (2018) Openness through sound: Dualcasting on Irish LGBT radio. Journal of Radio and Audio Media 24(2):224-239.

Kern R (2014) Imaging community: Visibility, bonding and L Word audiences. Sexualities 17(4): 434-450.

Lieb K (2016) Pop stars perform 'Gay' for the male gaze: The production of Fauxmosexuality in female Popular music performances and its representational Implications. In: Mayer V, Banks M and Conor B (eds) Production Studies: Cultural Studies of Global Media Industries, the Sequel. New York: Routledge, pp. 59-72.

Martin AL (2015) Scripting black gayness: Television authorship in black-cast sitcoms. Television \& New Media 16(7): 648-663.

Martin AL (2018a) Special issue on Queer Production Studies. Journal of Film and Video 70(3-4): $3-100$.

Martin AL (2018b) The queer business of casting gay characters on U.S. television. Communication, Culture \& Critique 11(2): 282-297.

Meyer R (1991) Rock Hudson's Body. In: Fuss D and Barale M (eds) Inside/Out: Lesbian Theories, Gay Theories. New York: Routledge, pp. 259-288.

Mullen P (2012) The Poor Bugger's Tool: Irish Modernism, Queer Labour and Postcolonial History. Oxford: Oxford University Press.

Ng E (2013) A 'Post-Gay' era? Media gaystreaming, homonormativity, and the politics of LGBT integration. Communication, Culture \& Critique 6: 258-283.

$\mathrm{Ng}$ E (2018) Contesting the queer subfield of cultural production: Paratextual framings of Carol and Freeheld. Journal of Film and Video 70(3-4): 8-23.

Russo V (1981) The Celluloid Closet: Homosexuality in the Movies. New York and London: Harper \& Row.

Schiappa E, Gregg PB and Hewes DE (2006) Can one TV show make a difference? Will \& Grace and the parasocial contact hypothesis. Journal of Homosexuality 51(4): 15-37.

Sender K (2012) No hard feelings: Reflexivity and queer affect in the new media landscape. In: Ross K (ed.) The Handbook of Gender, Sex, and Media. Malden, MA: Blackwell, pp. 207-225.

Vaid U (1995) Virtual Equality: The Mainstreaming of Gay and Lesbian Liberation. New York: Knopf Doubleday Publishing.

Vanlee F (2019) Acknowledging/denying LGBT+ difference: Understanding homonormativity and LGBT+ homogeneity in Flemish TV fiction through production research. European Journal of Communication 34(5): 520-534.

Wreyford N (2013) The real cost of childcare: Motherhood and project-based creative labour in the UK film industry. Studies in the Maternal 5(2): 50-65. 